DOI: $10.15593 / 24111678 / 2016.02 .08$

УДК 623.4+629.1+620.92

\author{
А.Г. Семёнов \\ Санкт-Петербургский государственный политехнический \\ университет Петра Великого (СПбПУ), Санкт-Петербург, Россия
}

АМФИБИЯ С СОЛНЕЧНОЙ БАТАРЕЕЙ

Разработка относится к амфибийным транспортным средствам (ТС) с автоматическим, полуавтоматическим и ручным дистанционным управлением по радиоканалу с возможным дублированием по гидроакустическому каналу, научно-исследовательского, военного и гражданского назначения, а также к альтернативным источникам энергии - солнечным батареям (СБ) на основе фотоэлектрических преобразователей в виде плоских панелей-модулей или сплошной криволинейной, в частности параболической, облицовки. Представлен аналитический экспресс-обзор аналогов предлагаемой разработки с указанием прототипа, с опорой на иллюстративный материал. При этом выборка охватывает сухопутные (обычной и высокой проходимости), водные, подводные ТС и предназначенные для обеих сред - собственно амфибии. В обзорную часть включены отечественные и зарубежные устройства - как выполненные «в металле», так и дизайнерские проекты. Сформулированы задача проекта и технический результат его реализации. Дано подробное техническое описание авторских технических предложений, в том числе концепция амфибии с двухфункциональной СБ: последняя задействована в создании силы плавучести для преодоления водной преграды. Приняты меры к патентованию идеи и результатов ее инженерной проработки. Инновационный проект находится на стадии технических предложений. Разработка дает технико-эксплуатационный или тактико-технический эффект (в приложении соответственно к гражданским и специальным или военным ТС). Главное преимущество предлагаемой концепции - рационализация компоновки амфибии с использованием стереометрической формы СБ. Таким образом, материал дан в развитие прорабатываемых автором, по меньшей мере, трех тем: двух- и более функциональность ТС; амфибийность ТС; транспортная робототехника.

Ключевые слова: транспортное средство высокой проходимости, амфибия, альтернативная энергетика, солнечная батарея, плавучесть, сила плавучести, герметизация, управление, робототехника.

\author{
A.G. Semenov \\ Peter the Great St.Petersburg Polytechnic University, \\ St.Petersburg, Russian Federation
}

\title{
AMPHIBIAN WITH SOLAR ELECTRIC GENERATOR
}

Development pertains to amphibian $(\mathrm{T})$ with automatic, floor-automatic and manual remote controls on radio link with possible duplication on hydra-acoustic channel, research, military and civil purpose, as well as to alternative source of the energy - a solar generator (SG), on base of the photoelectric converters in the manner of flat panels-modules or utter curvilinear, in particular parabolic, facing. Analytical express-review analogue proposed development is Given with instruction of the prototype, with handhold on illustrative material. At, the sample covers land (usual and high passability), water, undersea $\mathrm{T}$ and intended for both ambiences - strictly amphibians. In overview part are enclosed domestic and foreign device as executed "in metal", so and дизайнерские projects. The Worded problem of the project and technical result to his(its) realization. It Is Given detailed technical description of the author's technical offers, including concept to amphibians with two-functional SG: the last is used in 
creation of power to floatability for moving on water barrier. The Accepted measures to patenting the ideas and result of her(its) engineering design. The Innovative project is found on stage of the technical offers. The Development gives the technician-working or tactician-technical (in exhibit, accordingly, to civil and special or military T). The Main advantage proposed concepts - a rationalization of the arrangement to amphibians with use the geometric form SG. Thereby, material is given in development studied by author, to say the least, three that: possibility of the execution product in composition T twoand more function $\mathrm{T}$; the possibility of the motion $\mathrm{T}$ on land and on water; the transport robotics.

Keywords: transport facility to high passability, amphibian, alternative energy, solar generator, floatability, power to floatability, capsulation, management, robotics.

\section{Область исследования и технические предложения}

Представляемые вниманию научно-технического сообщества конкретные технические предложения относятся к амфибийным транспортным средствам (ТC) с автоматическим, полуавтоматическим и ручным дистанционным управлением по радиоканалу с возможным дублированием по гидроакустическому каналу) научно-исследовательского, военного и гражданского назначения, а также (одновременно) к альтернативным источникам энергии - солнечным батареям (СБ) на основе фотоэлектрических преобразователей (ФЭП).

\section{Аналитический экспресс-обзор аналогов и постановка задачи}

Широкое распространение получают не только сухопутные, но и водные самоходные ТС, оснащенные развитыми (т.е. с большой площадью фотоэлектрических преобразователей) СБ.

На рис. 1 показан автомобиль (Ecletic), содержащий самоходное шасси с сухопутным колесным движителем, несущим корпусом/рамой, жестко установленным/ой над ним/ней корпусной элемент, СБ, образованную крышей указанного элемента, облицованного снаружи ФЭП, а также систему управления [1].

Это сугубо наземное сухопутное невездеходное ТС, обитаемое, с ручным управлением, причем упомянутый корпусный элемент имеет коробчатую форму закрытого сверху выпуклой крышей параллелепипеда, соответственно, и панель ФЭП (облицовка) СБ - выпуклая.

Таким образом, это ТС, не относится, тем ни менее, к категории амфибийных роботов научно-исследовательского, военного или специального назначения, а его СБ однофункциональна - используется только по своему прямому назначению. 


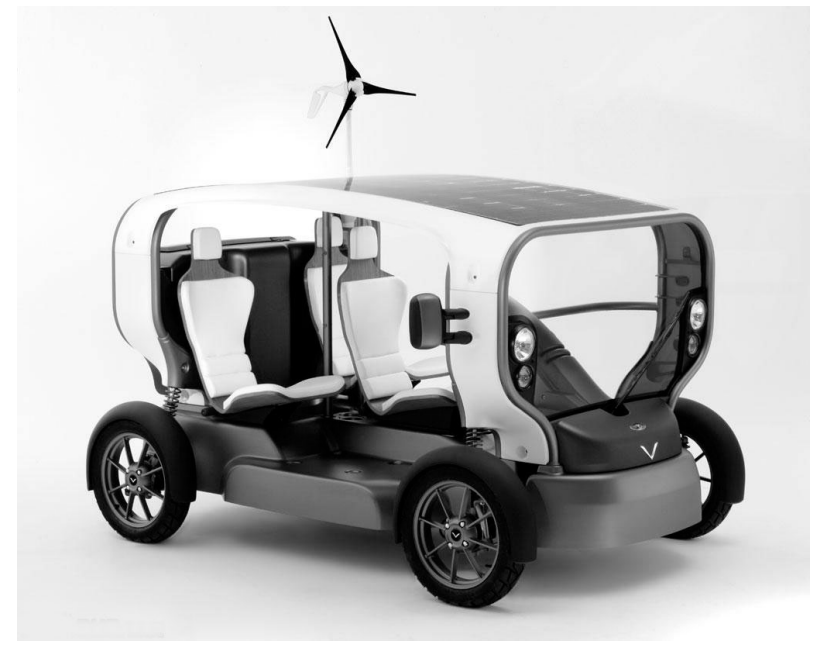

Рис. 1. Автомобиль Ecletic с СБ

Сюда же можно отнести и пример водного ТС: на рис. 2 показана прогулочная яхта, содержащая несущий корпус с положительной плавучестью, специализированный водоходный движитель, СБ, образованную изогнутым элементом с верхней поверхностью, облицованной ФЭП, и установленную на несущем корпусе выше его уровня, а также систему управления [2]. Это сугубо водное ТС («новая ультралегкая футуристическая и экологически чистая яхта, работающая на энергии солнца и ветра»), обитаемое, с ручным управлением, причем упомянутый изогнутый элемент двухфункционален (крыша открытого салона и одновременно основа для установки панелей ФЭП СБ), имеет форму выпуклого крыла, соответственно, и облицовка СБ - также выпуклая.

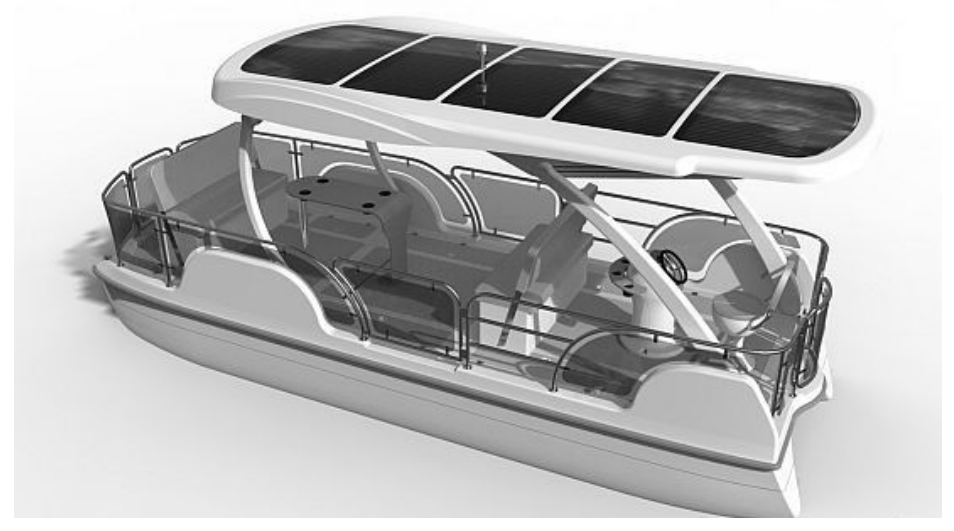

Рис. 2. Яхта с СБ 
Таким образом, и это ТС не относится к категории амфибийных роботов научно-исследовательского, военного или специального назначения, а его СБ хотя и двухфункциональна, но не используется (да и не может использоваться) для создания силы плавучести (архимедовой силы).

В то же время в технике известны примеры конструктивного совмещения СБ с устройствами другого назначения, с целью реализации принципа двух- или многофункциональности, позволяющего получать выигрыш в массогабаритных показателях. Здесь можно назвать:

- ТС, в том числе вездеходные (танки), содержащие установленные на них развитые СБ, конструктивно совмещенные в одном изделии с элементами (крышками) динамической защиты [3];

- облицованные панелями ФЭП крупногабаритные несущие плоские элементы, попеременно выполняющие функции парусов ТС на плаву и крыльев этого же ТС в воздухе [4];

- военное обмундирование с компактными СБ, конструктивно совмещенными со знаками различия на погонах $[5,6]$.

Однако это носит ограниченно-целевой (частный) характер и не исчерпывает всего возможного разнообразия воплощения принципа двух- и многофункциональности.

В свою очередь к широкому классу вездеходных ТС относятся и амфибийные (плавающие) машины, способные как перемещаться по суше, так и преодолевать водные преграды, главным образом, вплавь при положительной их плавучести, у которых корпус также как минимум двухфункционален - выполняет функции несущего элемента шасси, водоизмещающего элемента (с расчетной ватерлинией на уровне корпуса ниже верхних его кромок) и др., при этом емкость корпуса (внутренний его объем) гидроизолируют снизу и предусматривают аварийное устройство откачки воды из указанной емкости [7-9].

Среди них можно обнаружить (рис. 3) колесный полноприводный автомобиль-амфибию с СБ на плоских подложках на выпуклой крыше обитаемого коробчатого корпуса [10].

Но в приведенном примере СБ (элементы-подложки плюс панели ФЭП) - плоско-выпуклая и не является водоизмещающей (т.е. создающей силу плавучести).

Интересен с точки зрения авторского предмета исследования и разработки дизайн-проект прогулочной амфибии с трансформируемой (поворотной и распускаемой веером) двухфункциональной (она же од- 
новременно - парус) СБ (рис. 4), установленной на крыше коробчатого элемента с обитаемым салоном, жестко установленного на водоизмещающем шасси с сухопутно-водным колесным движителем и специализированными водоизмещающими поплавками в расчете (сомнительном, однако), что расчетная ватерлиния будет ниже уровня коробчатого элемента [11].

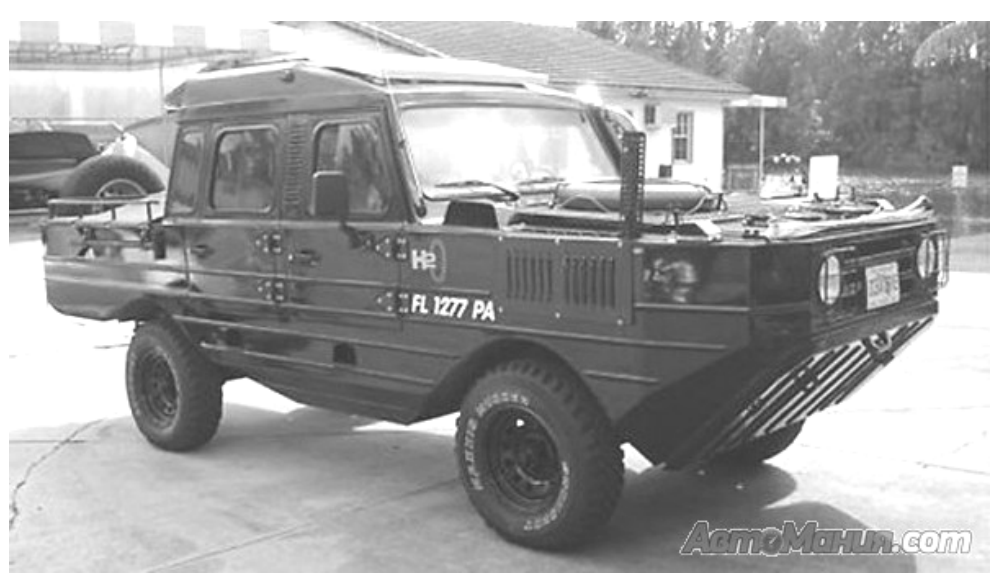

Рис. 3. Амфибия $H 2-0$ с СБ

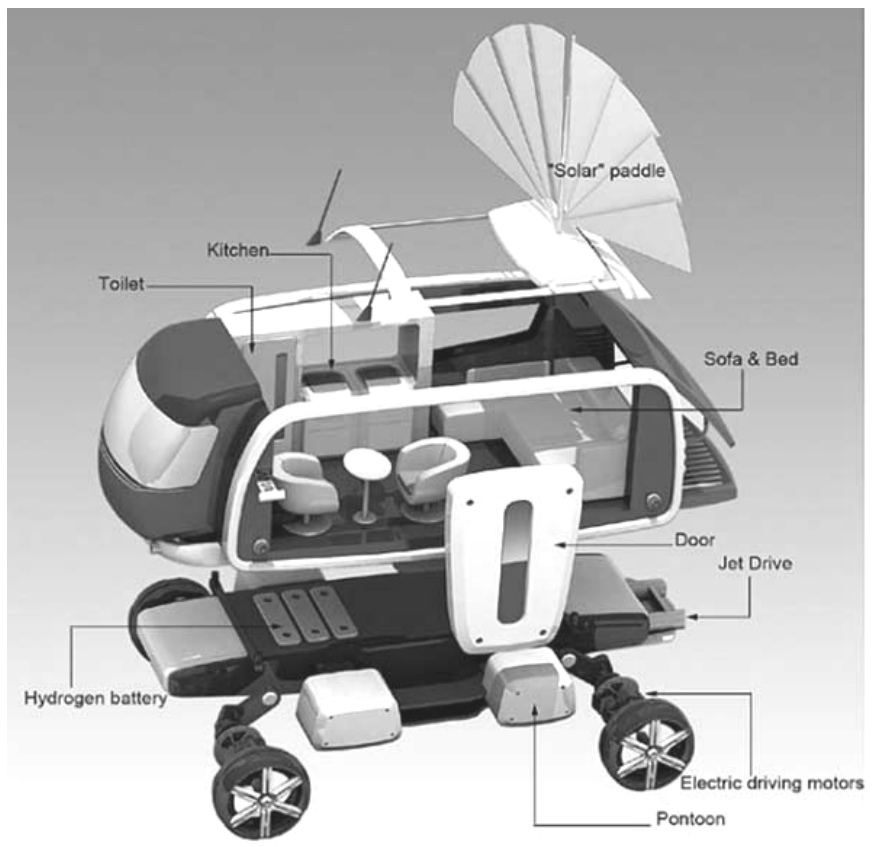

Рис. 4. Трансформируемая амфибия с двухфункциональной СБ 
Это ТС имеет тот же недостаток, что и устройство, представленное на рис. 2.

Обратимся теперь к ситуации в робототехнике. На рис. 5 показан водный дрон с плоской частично водоизмещающей платформой (герметичным корпусом), установленной на ней также плоской СБ в виде множества панелей ФЭП и системой управления внутри платформы, не считая наружной телескопической антенны [12]. Однако он не приспособлен для эксплуатации на суше (собственно, такой задачи и не ставилось), а СБ при такой компоновке и конфигурации надводных элементов весьма подвержены воздействию воды - как морской забортной, так и осадкам, к тому же невозможно управление углами наклона СБ в целях оптимизации ее направленности на Солнце.

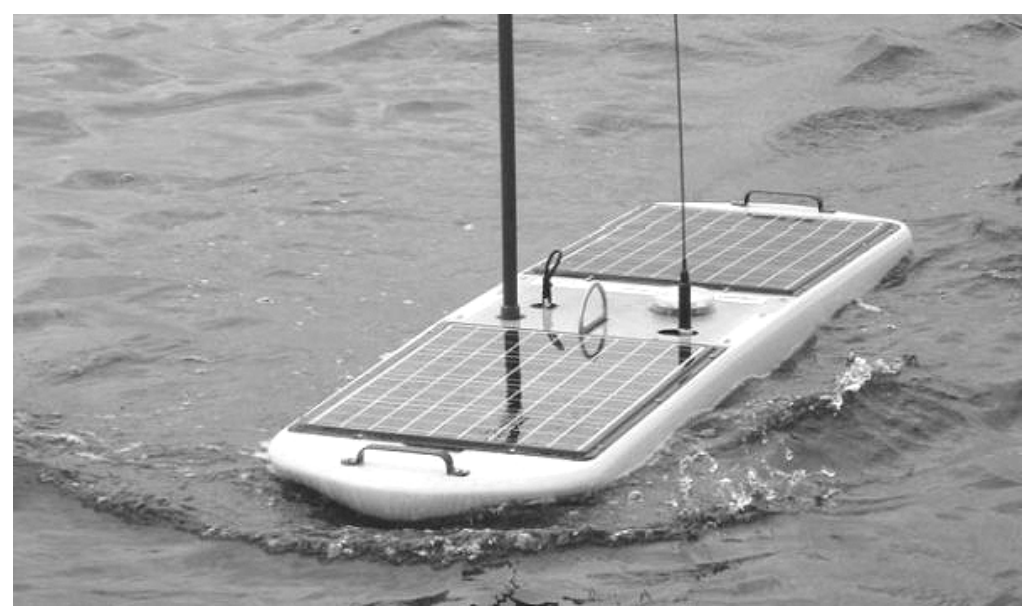

Рис. 5. Плавающий дрон с СБ для мониторинга морей и океанов

Кстати, известны и другие водоизмещающие элементы, имеющую положительную плавучесть, с облицовкой ФЭП. В частности:

- подводно-надводный туристический аппарат (рис. 6) с погруженной в воду центральной прозрачной обитаемой капсулой и прикрепленными к ней боковыми поплавками с облицовкой ФЭП их верхней выпуклой поверхности [13];

- морская стационарная солнечная электростанция (рис. 7), содержащая множество водоизмещающих поплавков типа «бакен», соединенных тросами или иной гибкой связью друг с другом, с якорем и индивидуальными подводными грузами-стабилизаторами, с облицовкой ФЭП надводной выпуклой части поверхности [14]. 


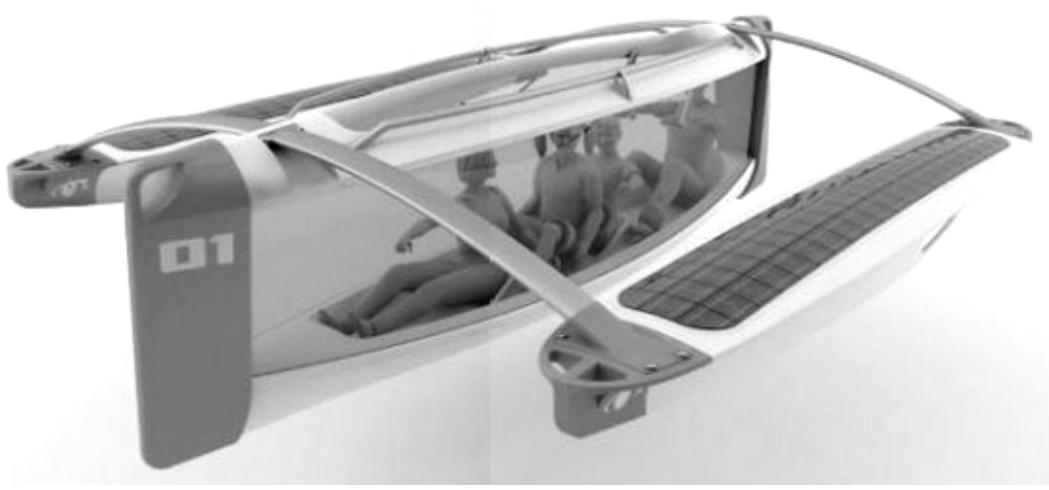

Рис. 6. Подводная лодка Reef Explorer с СБ

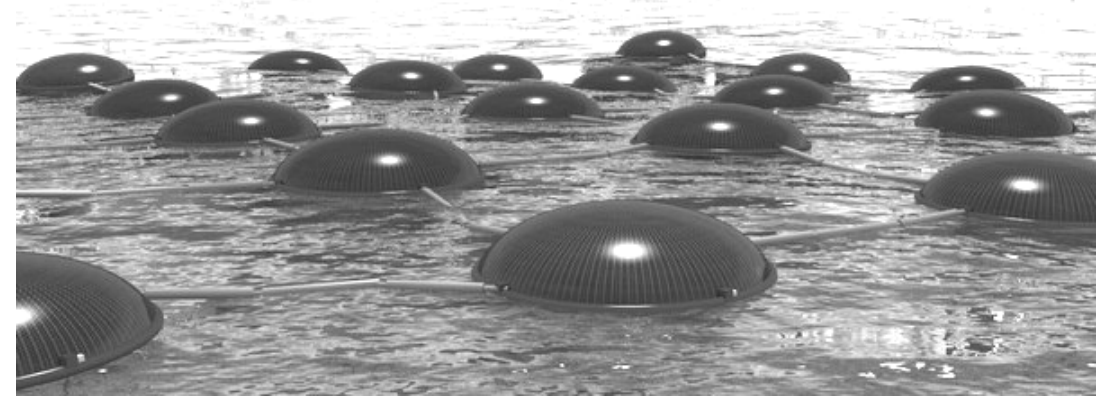

Рис. 7. Морская гелеоэлектростанция Marine Solar Cells

Однако и они не относятся к категории амфибийных роботов, а их СБ хотя и двухфункциональны (если водоизмещающие поплавки относить к составной части СБ наряду с ФЭП), но в первом примере СБ расположены на уровне несущего корпуса, во втором - отсутствует система управления, а в обоих примерах подвержены интенсивному воздействию водной стихии.

Близким к предлагаемому устройству по назначению и количеству общих конструктивных признаков аналогом является амфибийное ТС («Автобус-амфибия с ветроэнергетической установкой и СБ»), содержащее самоходное шасси с универсальным сухопутно-водоходным движителем (колеса с выдвижными лопастями) и несущей рамой, элемент - кузов, СБ, установленную на элементе - кузове выше его уровня (на крыше), а также систему управления с питанием от буферного электрического аккумулятора [15]. ТС выполнено амфибийным, с положительной плавучестью и водозащитным исполнением шасси, при сохранении работоспособности СБ и ТС в целом на плаву. Однако 
с обитаемым коробчатым элементом - кузовом и неподвижным креплением СБ относительно рамы шасси, а расчетная ватерлиния находится явно гораздо ниже солнечной батареи, т.е. не используется объем, занимаемый СБ, для создания силы плавучести.

За прототип (ближайший аналог) принята знаменитая подвижная научно-исследовательская лаборатория «Луноход» с возможностью ручного дистанционного управления, содержащая самоходное шасси, по крайней мере с сухопутным движителем (который в принципе может использоваться и как водоходный, но неспециализированно-водоходным, малоэффективным) и несущим корпусом, СБ, образованную чашеобразным элементом с вогнутой поверхностью, облицованной панелями ФЭП, и поворотно относительно несущего корпуса установленную на несущем корпусе выше его уровня, а также систему управления с питанием от буферного электрического аккумулятора $[16,17]$.

Если в конкретном практическом (и историческом) приложении «Луноход-1» и «Луноход-2» и не нуждались в амфибийных свойствах (плавучести, ходкости, маневренности и живучести на плаву) по причине отсутствия воды на Луне, то для других вероятных вездеходных транспортных роботов, прежде всего наземных, имя которым «легион» (научно-исследовательского, военного и специального назначения), отсутствие свойств амфибии может являться весьма существенным недостатком всего робототехнического комплекса.

Таким образом, «Луноход» как прототип (в расширительном смысле, в контексте авторских технических предложений!) еще недостаточно совершенен по своим технико-эксплуатационным (тактикотехническим) характеристикам.

Поэтому задача, на решение которой направлена нижеописываемая разработка, заключается в повышении технико-эксплуатационных (тактико-технических) характеристик вездеходного транспортного робота прежде всего за счет расширения функционального назначения чашеобразного элемента СБ с целью обеспечения положительной плавучести всего робота при сохранении его работоспособности.

\section{Комплекс технических предложений}

Решение поставленной задачи достигается тем, что вездеходный транспортный робот (с возможностью ручного дистанционного управления и оперативного перепрограммирования), содержащий самоходное шасси, по крайней мере с сухопутным движителем и несущим 
корпусом, солнечную батарею, образованную чашеобразным элементом с вогнутой поверхностью, облицованной фотоэлектрическими элементами, и поворотно относительно несущего корпуса установленную на несущем корпусе выше его уровня, а также систему управления с питанием от буферного электрического аккумулятора, выполнен амфибийным с положительной плавучестью, водозащитным исполнением шасси и расчетной ватерлинией на уровне чашеобразного элемента солнечной батареи ниже верхнего его края, т.е. с использованием части объема солнечной батареи для создания силы плавучести транспортного робота при сохранении работоспособности солнечной батареи и всего робота на плаву.

В порядке решения поставленной задачи заявляемое устройство может характеризоваться следующими совокупностями дополнительных конструктивных признаков (при сформулированной выше основной совокупности признаков):

- вездеходный транспортный робот может быть снабжен устройством горизонтирования чашеобразного элемента солнечной батареи (это позволяет не только свести к минимуму вероятность притопления чашеобразного элемента с солнечной облицовкой / солнечными панелями на плаву, обусловленного возможным креном и/или дифферентом чашеобразного элемента, но и поднять высоту расчетной ватерлинии для обеспечения большей силы плавучести транспортного робота в целом);

- при указанной выше совокупности признаков устройство горизонтирования чашеобразного элемента солнечной батареи может быть выполнено в виде следящего электромеханического привода (это позволяет оперативно изменять углы взаимного положения корпуса/рамы шасси и чашеобразного элемента с солнечной облицовкой / солнечными панелями при входе в воду, особенно крутым берегом, и выходе из воды, крене и дифференте на плаву в любом направлении);

- внутренний свободный объем чашеобразного элемента солнечной батареи может быть гидроизолирован от внутреннего свободного объема несущего корпуса шасси (это позволяет исключить в штатном режиме эксплуатации притопление солнечной батареи и связанное с этим уменьшение запаса плавучести транспортного робота);

- вездеходный транспортный робот может быть дополнительно снабжен аварийным водооткачивающим устройством на основе насоса, с возможностью принудительного удаления воды из внутреннего сво- 
бодного объема чашеобразного элемента солнечной батареи (это позволяет оперативно удалять воду с солнечных панелей в аварийном режиме притопления солнечной батареи);

- вездеходный транспортный робот может быть дополнительно снабжен сливным клапаном в районе нижней точки пустого объема чашеобразного элемента солнечной батареи, с возможностью ручного и/или дистанционного его открытия/закрытия (это позволяет избежать притопления солнечной батареи жидкими осадками сверху или воздействия конденсата);

- вездеходный транспортный робот может быть дополнительно снабжен водоходным движителем (это повышает водоходные качества транспортного робота как амфибии - ходкость, маневренность и др.).

Основную изобретательскую идею заявляемого технического решения можно сформулировать, иными словами, следующим образом: предлагается конструктивно и функционально объединить в одном имеющемся у прототипа устройстве (фрагменте), а именно - открытом сверху чашеобразном (в частности, «параболическом») теле, во-первых, «остронаправленную» солнечную батарею и, во-вторых, эффективно водоизмещающую емкость (с характерной для плавсредств стереометрической формой, обеспечивающей положительную плавучесть). Соответственно, имеет место «сверхэффект» в патентоведческом понимании этого термина и наличие изобретательского уровня заявляемого технического предложения (неочевидность для специалистов из достигнутого уровня науки и техники).

\section{Краткое описание устройства по проекту «Амфибия с водоизмещающей управляемой солнечной батареей»}

Вездеходный транспортный робот содержит самоходное шасси 1 , по крайней мере с сухопутным движителем 2 (который может, в принципе, быть одновременно и водоходным, что свойственно, например, колесным, колесно-шагающим, гусеничным и др.) и несущим корпусом 3 (или несущей рамой 3 , что не принципиально).

На корпусе (раме) 3 установлен чашеобразный (в частности, с параболической формой в вертикальном сечении) элемент (ЧОЭ) 4 из водонепроницаемого материала (металл, пластик или др.), с размещенными в нем (по вогнутой поверхности) панелями ФЭП 5, с образованием развитой СБ 4-5. При этом элемент 4 установлен выше уровня не- 
сущего корпуса (рамы) 3 и может быть горизонтален (по верхнему краю 6) при горизонтальности корпуса (рамы) 3.

Принципиально, что робот выполнен амфибийным, с положительной плавучестью (и запасом плавучести), водозащитным исполнением шасси 1 и расчетной ватерлинией WL (рис. 8) на уровне СБ 4-5, точнее - ее чашеобразного элемента 4 ниже верхнего его края 6 , т.е. с использованием части объема чашеобразного элемента 4 СБ 4-5 для

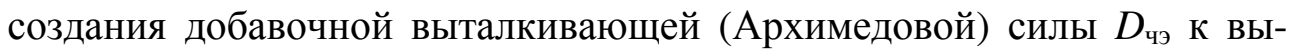
талкивающей (архимедовой) силе $D_{\text {ш }}$ шасси в обеспечение силы плавучести $D=D_{\text {чэ }}+D_{\text {ш }}$ шасси робота в целом при сохранении работоспособности СБ 4-5 (панелей 5 в их электрической взаимосвязи) и робота в целом в режиме его эксплуатации на плаву.

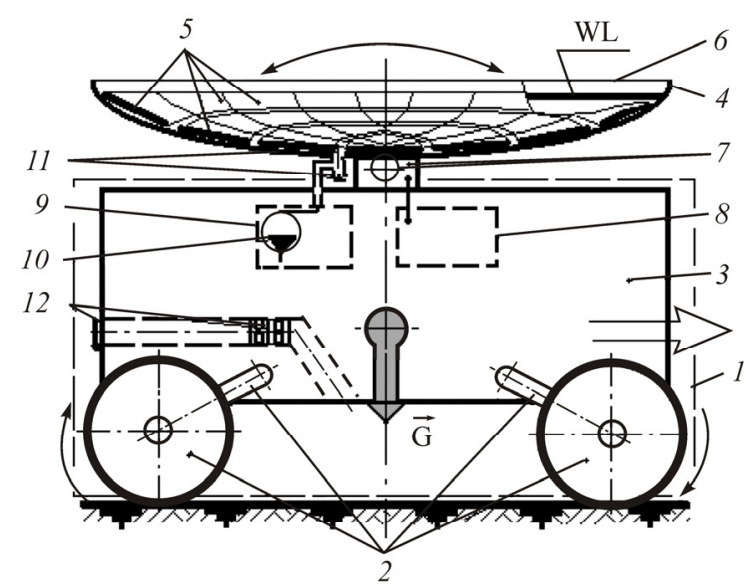

Рис. 8. Устройство транспортного средства - амфибии, вид сбоку на суше: WL - расчетная ватерлиния

Положение WL на ЧОЭ 4 обеспечивают на этапе проектирования (конструкторской проработки) подбором массогабаритных характеристик составных частей на основе уравнения плавучести:

$$
G=\rho \cdot g \cdot\left(D_{\text {ш }}+D_{\text {чэ }}\right),
$$

где $\rho$ - плотность забортной воды; $g$ - ускорение свободного падения.

Дальнейшее описание устройства относится к дополнительным признакам, которые не обязательны, но рациональны и поэтому рекомендуются к использованию.

Робот может быть снабжен устройством горизонтирования 7 чашеобразного элемента 4, а значит, СБ 4-5 в целом. В частности, устройство 7 может представлять собой быстродействующий следящий 
электромеханический привод, работающий от электрического аккумулятора (в том числе буферного) 8, при солнечной батарее 4-5 (панели 5).

Внутренний свободный объем чашеобразного элемента 4 гидроизолирован не только от водной среды снизу-сбоку (что обязательно для водоизмещающего тела и оговорено признаком «водонепроницаемые стенки»), также может быть гидроизолирован от внутреннего свободного объема несущего корпуса 3 шасси 1 известными в инженерном деле средствами, например резиновым уплотнением 9.

Робот может быть дополнительно снабжен аварийным водооткачивающим устройством 9 на основе жидкостного (водяного) насоса 10 , с возможностью принудительного удаления воды из внутреннего свободного объема чашеобразного элемента 4 в случае притопления или осадков сверху.

Что касается упомянутых осадков, то, во избежание скопления жидких осадков в элементе 4 , конкретно - в районе нижней точки пустого (открытого) объема чашеобразного элемента 4, рекомендуется предусмотреть сливной клапан 11 с ручным и/или дистанционным открытием/закрытием. При этом может быть задействовано как естественное гравитационное поле, так и упомянутое устройство 9-10 путем его параллельного подключения к отсасывающей магистрали.

Робот может быть дополнительно снабжен специализированным водоходным движителем 12, например водометами или винтами с соответствующими приводами на корме слева и справа (см. рис. 8,9 ).

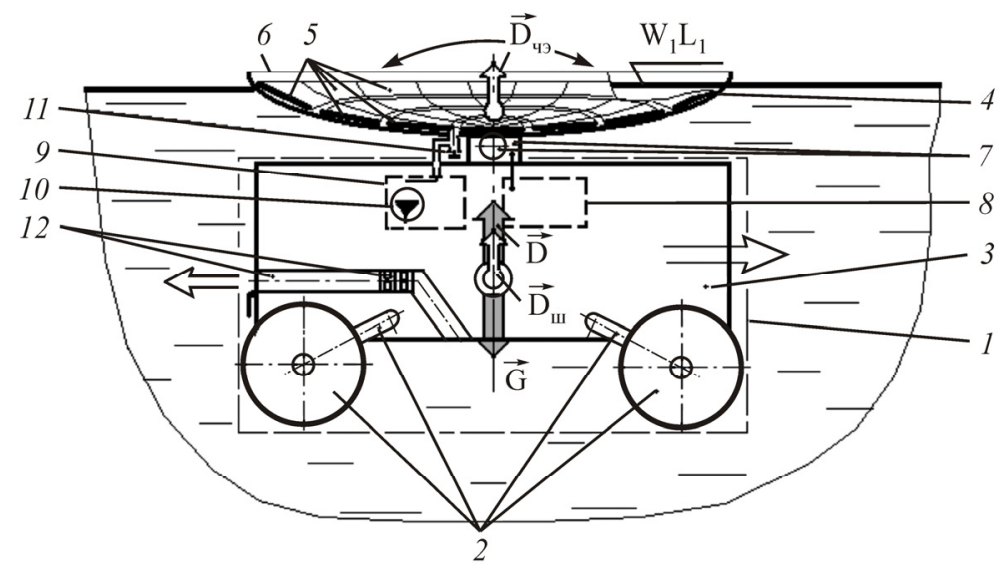

Рис. 9. Транспортное средство - амфибия, вид сбоку на плаву: $\mathrm{W}_{1} \mathrm{~L}_{1}$ - действующая ватерлиния; $\vec{G}-$ вес амфибии; $\vec{D}$ - сила плавучести амфибии, в том числе $\vec{D}_{\text {ш }}$ - доля шасси в силе плавучести; $\vec{D}_{\text {чэ }}$ - доля чашеобразного элемента солнечной батареи 
Не исключены другие устройства (варианты) в рамках изложенных технических предложений. Выбор конкретного варианта из рассмотренных при использовании предложений зависит от спектра требований и производится в каждом конкретном случае. Разработка не претендует на полное замещение близких аналогов. Устройство предназначено для ограниченного применения там, где может дать максимальную эффективность.

\section{Краткое описание работы (использования) устройства по проекту «Амфибия с водоизмещающей управляемой солнечной батареей»}

При эксплуатации на суше (основные эксплуатационные условия) робот покоится или перемещается на шасси 1 (рис. 6) за счет сухопутного (колесного) движителя 2, пребывающего в силовом взаимодействии с грунтом. При этом ЧОЭ 4 либо находится в исходном ровном положении (без наклона относительно корпуса/рамы 3 шасси 1), либо принудительно наклонен в сторону Солнца (для это может быть использовано, в принципе, и устройство 7) для большей эффективности использования солнечной энергии для ее преобразования в электрическую и передачи в буферный аккумулятор 8 для дальнейшего использования бортовыми устройствами - потребителями электроэнергии, в том числе двигателями (двигателем) движителя 2 в составе шасси 1. Сливной клапан 11 в ЧОЭ 4, как правило, открыт, вследствие чего возможные влажные осадки и конденсат удаляются автоматически под действием сил гравитации или принудительно за счет откачивающего устройства 9 с насосом 10. Имеется возможность слива воды из ЧОЭ 4 и путем его наклона за счет устройства 7.

При преодолении водной преграды (неосновные, временные эксплуатационные условия) робот перемещается в морской или пресной воде (см. рис. 9) за счет либо специализированного водоходного движителя 12 , либо сухопутного (колесного) движителя 2 , либо того и другого, пребывающих в силовом взаимодействии с окружающей средой, главным образом с водной стихией. При этом рекомендуется использовать заранее запасенную в достаточном для преодоления водной преграды и выхода на противоположный берег количестве электроэнергию в аккумуляторе 8 , поскольку на плаву робот лишен возможности наклона ЧОЭ 4 на существенные углы при низком положении Солнца. Динамика и кинематика перемещения робота на плаву не 
содержит чего-либо ранее неизвестного в физике, в теории и практике взаимодействия «амфибия - водная преграда» (см. рис. 7-9). Чашеобразная форма элемента 4 способствует его остойчивости и затрудняет волнообразование как функцию скорости.

Робот погружен в воду (действующая ватерлиния $\mathrm{W}_{1} \mathrm{~L}_{1}$ на рис. 9), в идеале, по расчетную ватерлинию WL на уровне ЧОЭ 4 (см. рис. 8) ниже края 6 (в обеспечение заданного запаса плавучести), но с образованием добавочной выталкивающей силы $D_{\text {чэ }}$ к выталкивающей силе $D_{\text {ш }}$ шасси в обеспечение силы плавучести $D=D_{\text {чэ }}+D_{\text {ш }}$ шасси робота в целом.

При дифференте и крене шасси 1 в динамике робота, устройство 9 автоматически отслеживает (как и надлежит следящему приводу), например по показаниям продольного и поперечного уровней, горизонтальное положение ЧОЭ 4.

Клапан 11 закрыт и не пропускает забортную воду во внутреннее пространство ЧОЭ 4, а при притоплении его фотоэлектрической облицовки 5 осадками или конденсатом включается (включают) насос 10 и жидкость через заборное отверстие устройства 9 удаляется за борт ЧОЭ 4. Аналогично удаляется вода, по той или иной причине (превышение высоты волн, качка при отказе стабилизатора - устройства 7 горизонтирования ЧОЭ 4 и др.) захлестнувшая через край 6 ЧОЭ 4.

\section{Эффективность устройства по проекту «Амфибия с водоизмещающей управляемой солнечной батареей»}

Использование технических решений позволяет улучшить технико-эксплуатационные (тактико-технические) характеристики вездеходного робота прежде всего за счет расширения функционального назначения чашеобразного элемента СБ с целью обеспечения положительной плавучести робота при сохранении его работоспособности.

К моменту завершения статьи проект находится на стадии технических предложений.

Предприняты необходимые меры к защите идеи и результатов ее инженерной проработки как объекта интеллектуальной собственности в установленном порядке. 


\section{Заключение}

Авторская разработка «Амфибия с водоизмещающей управляемой солнечной батареей» характеризуется новизной, изобретательским уровнем, практической готовностью к промышленной реализации и позволяет повысить технико-эксплуатационные (тактико-технические) характеристики вездеходного робота.

\section{Список литературы}

1. Авто на солнечных батареях - прорыв в будущее или тупиковая ветвь? [Электронный ресурc]. - URL: http://mirenergii.ru/energiyasolnca/ avto-na-solnechnyx-batareyax-proryv-v-budushhee-ili-tupikovaya-vetv.html (дата обращения: 16.05.2016).

2. Водный транспорт на солнечной энергии [Электронный реcypc]. - URL: http://topneftegaz.ru/news/view/99656 (дата обращения: 16.05.2016).

3. Пат. 2514965 Российская Федерация. Бронированный объект с динамической защитой и электрооборудованием / А.Г. Семёнов. МПК F41H 5/007, H01L 25/00, H02N 6/00, 12.03.2014, № 2013101831/11, заявл. 15.01.2013; опубл. 10.05.214, Бюл. № 13.

4. Креативный концепт транспорта-трансформера будущего [Электронный ресурc]. - URL: http://prointeresnoe.ru/kretivnyj-koncepttransporta-transformera-budushhego.html (дата обращения: 16.05.2016).

5. Пат. 2568792 Российская Федерация. Муфта погона / А.Г. Семенов. МПК A41D 29/00, Н 01 L 25/00, № 2014150368/12, заявл. 11.12.2014; опубл. 20.11.2015, Бюл. № 32.

6. Пат. 2579340 Российская Федерация. Съемный погон-муфта / А.Г. Семенов. МПК A41D 29/00, Н 01 L 25/00, № 2014150377/12, заявл. 12.12.2014; опубл. 10.04.2016, Бюл. № 10.

7. Аксенов П.В., Кононович Ю.А. Плавающие колесные и гусеничные машины. Конструкция, теория и расчет. - М.: Воениздат МО CCCP, 1963. - $271 \mathrm{c}$.

8. Степанов А.П. Плавающие машины. - М.: Изд-во ДОСААФ, 1975. - $192 \mathrm{c}$.

9. Степанов А.П. Конструирование и расчет плавающих машин. - М.: Машиностроение, 1983. - 200 с.

10. Н2-0: автомобиль-амфибия выставлен на еВау [Электронный pecypc]. - URL: http://avtomaniya.com/ site/publication-full/2741 (дата обращения: 16.05.2016). 
11. Проект необычного автодома [Электронный ресурс]. - URL: http:// camper4x4.ru/blog/yumor/274.html (дата обращения: 16.05.2016).

12. Четыре плавающих робота побили мировой рекорд дальности [Электронный ресурс]. - URL: http://nauka21vek.ru/archives/30273 (дата обращения: 16.05.2016).

13. Подводная лодка Reef Explorer, работающая на солнечных батареях [Электронный ресурc]. - URL: http://be-active.com.ua/interesting/ 1028-reef-explorer.html (дата обращения: 16.05.2016).

14. Солнечные батареи Marine Solar Cells на плаву [Электронный pecypc]. - URL: www.marineinsight.com (дата обращения: 16.05.2016).

15. Заявка 2006111355 Российская Федерация. Автобус-амфибия с ветроэнергетической установкой и солнечной батареей / В.А. Киселев. МПК D60K 1/00, заявл. 07.04.2006; опубл. 10.11.2007, Бюл. № 31.

16. Автоматические станции для изучения поверхностного покрова Луны / А.Л. Кеурджиан [и др.]. - М.: Машиностроение, 1976. 200 c. - C. $108-111$.

17. Семёнов А. Частная космическая история. Мемуары. - Berlin Leipzig, Deutchland: YAM LAMBERT Academic Publishing, 2012. - C. 13.

\section{References}

1. Avto na solnechnykh batareiakh - proryv v budushchee ili tupikovaia vetv'? [Car solar powered - breakthrough or dead end?], available at: http://mirenergii.ru/energiyasolnca/avto-na-solnechnyx-batareyax-proryv-vbudushhee-ili-tupikovaya-vetv.html (accessed 16 May 2016).

2. Vodnyi transport na solnechnoi energii [Water transport is solar powered], available at: http://topneftegaz.ru/news/view/99656 (accessed 16 May 2016).

3. Semenov A.G. Bronirovannyi ob"ekt s dinamicheskoi zashchitoi i elektrooborudovaniem [Armored object with dynamic protection and electrical equipment]. Patent 2514965 Rossiiskaia Federatsiia.

4. Kreativnyi kontsept transporta-transformera budushchego [Creative concept of transport-future transformer], available at: http://prointeresnoe.ru/ kretivnyj-koncept-transporta-transformera-budushhego.html (accessed 16 May 2016).

5. Semenov A.G. Mufta pogona [Clutch shoulder strap]. Patent 2568792 Rossiiskaia Federatsiia.

6. Semenov A.G. S"emnyi pogon-mufta [Removable shoulder strap clutch]. Patent 2579340 Rossiiskaia Federatsiia. 
7. Aksenov P.V., Kononovich Iu.A. Plavaiushchie kolesnye i gusenichnye mashiny. Konstruktsiia, teoriia i raschet [Floating wheeled and tracked vehicles. Design, theory and calculation]. Moscow: Voenizdat MO SSSR, 1963. $271 \mathrm{p}$.

8. Stepanov A.P. Plavaiushchie mashiny [Floating machine]. Moscow: DOSAAF, 1975. 192 p.

9. Stepanov A.P. Konstruirovanie i raschet plavaiushchikh mashin [Design and calculation of the floating machines]. Moscow: Mashinostroenie, 1983. $200 \mathrm{p}$.

10. H2-0: avtomobil'-amfibiia vystavlen na eBay [H2-0: the amphibious vehicle is exhibited on eBay], available at: http://avtomaniya.com/ site/publication-full/2741(accessed 16 May 2016).

11. Proekt neobychnogo avtodoma [The project is unusual motorhomes], available at: http:// camp-er4x4.ru/blog/yumor/274.html (accessed 16 May 2016).

12. Chetyre plavaiushchikh robota pobili mirovoi rekord dal'nosti [Four floating robot broke the world distance record], available at: http://nauka21 vek.ru/archives/30273 (accessed 16 May 2016).

13. Podvodnaia lodka Reef Explorer, rabotaiushchaia na solnechnykh batareiakh [Submarine Reef Explorer which works by solar batteries], available at: http://be-active.com.ua/interesting/1028-reef-explorer.html (accessed 16 May 2016).

14. Solnechnye batarei Marine Solar Cells na plavu [Solar panels Marine Solar Cells afloat], available at: www.marineinsight.com (accessed 16 May 2016).

15. Avtobus-amfibiia s vetroenergetiche-skoi ustanovkoi i solnechnoi batareei [The amphibious bus with the wind power installation and solar battery]. Zaiavka 2006111355 Rossiiskaia Federatsiia.

16. Kemurdzhian A.L. [et al.]. Avtomaticheskie stantsii dlia izucheniia poverkhnostnogo pokrova Luny [Automatic stations to study the surface cover of the moon]. Moscow: Mashinostroenie, 1976. 200 p.

17. Semenov A. Chastnaia kosmicheskaia istoriia. Memuary [Private space story. Memoirs]. Saarbrucken - Berlin - Leipzig, Deutchland: YAM LAMBERT Academic Publishing, 2012. 13 p.

Получено 18.05.2016 


\section{Об авторе}

Семёнов Александр Георгиевич (Санкт-Петербург, Россия) кандидат технических наук, доцент и ведущий научный сотрудник кафедры «Двигатели, автомобили и гусеничные машины» Института энергетики и транспортных систем Санкт-Петербургского политехнического университета Петра Великого, старший научный сотрудник, почетный изобретатель Европы, академик ЕАЕН, МАНЭБ, МАС, ПАНИ, чл.-корр. АВН (195251, Санкт-Петербург, ул. Политехническая, 29, e-mail: agentnomer117@mail.ru).

\section{About the author}

Aleksandr G. Semenov (St. Petersburg, Russian Federation) - Ph.D. in Technical Sciences, Associate Professor and Leading Researcher, Department of Engines, Cars and Caterpillar Machines, Institut of Energy and Transport Systems, Peter the Great St.Petersburg Polytechnic University, Senior Researcher, the Real Member (the Academician) to European Academy of the Natural Sciences, International Academy of the Sciences to Ecologies and Safety to Vital Activity, International Academy Social Technology, Peter Academies of the Sciences, Associate Member of the Military Sciences Academies (29, Politekhnicheskaia st., St.Petersburg, 614990, Russian Federation, e-mail: agentnomer117@mail.ru). 